\title{
CC chemokine ligand 20 and its cognate receptor CCR6 in mucosalT cell immunology and inflammatory bowel disease: odd couple or axis of evil?
}

\author{
Adrian Y. S. Lee ${ }^{1,2}$, Rajaraman Eri ${ }^{3}$, Alan B. Lyons ${ }^{2}$, Michael C. Grimm ${ }^{4}$ and Heinrich Korner ${ }^{1}{ }^{*}$ \\ ${ }^{1}$ Menzies Research Institute Tasmania, University of Tasmania, Hobart, TAS, Australia \\ 2 School of Medicine, University of Tasmania, Hobart, TAS, Australia \\ ${ }^{3}$ School of Human Life Sciences, University of Tasmania, Launceston, TAS, Australia \\ ${ }^{4}$ St. George Clinical School, University of New South Wales, Sydney, NSW, Australia
}

\section{Edited by:}

Rajaraman D. Eri, University of

Tasmania, Australia

\section{Reviewed by:}

Phil Sutton, Murdoch Children's

Research Institute, Australia

Sukanya Raghavan, University of

Gothenburg, Sweden

\section{*Correspondence:}

Heinrich Korner, Menzies Research Institute Tasmania, Medical Science 2, 17 Liverpool Street, Hobart, TAS 7000, Australia

e-mail: heinrich.korner@utas.edu.au
Chemokines and their cognate receptors have been identified as major factors initiating and governing cell movement and interaction. These ligands and their receptors are expressed on a wide variety of cells and act during steady-state migration as well as inflammatory recruitment. CCR6 is a non-promiscuous chemokine receptor that has only one known chemokine ligand, CCL20, and is present on B and T cells as well as dendritic cells (DCs). Two $\mathrm{CD}^{+}{ }^{+} \mathrm{T}$ cell populations with opposing functions present in the intestines and the mesenteric lymph nodes express CCR6: the pro-inflammatory $T_{H} 17$ and regulatory $T_{\text {reg }}$ cells. CCL20 is also present in the intestine and is strongly up-regulated after an inflammatory stimulus. Interestingly, this ligand is also expressed by $T_{H} 17$ cells, which opens up the possibility of autocrine/paracrine signaling and, consequently, a self-perpetuating cycle of recruitment, thereby promoting inflammation. Recently, CCR6 has been implicated in inflammatory bowel disease (IBD) by genome wide association studies which showed an association between SNPs in the genomic region of the CCR6 gene and the inflammation. Furthermore, recent research targeting the biological function of CCR6 indicates a significant role for this chemokine receptor in the development of chronic IBD. It is therefore possible that IBD is facilitated by a disordered regulation of $T_{H} 17$ and $T_{\text {reg }}$ cells due to a disruption in the CCL20-CCR6 axis and consequently disturbed mucosal homeostasis. This review will summarize the literature on CCL20-CCR6 in mucosal immunology and will analyze the role this receptor-ligand axis has in chronic IBD.

Keywords: inflammatory bowel diseases, Th17 cells, $\mathrm{T}_{\text {reg }}$ cells, CCR6, CCL20

\section{CHEMOKINES: BIOCHEMISTRY AND FUNCTION}

The chemokine family is a large collection of positively charged small cytokines that have been shown to be important cues in the chemotactic navigation of leukocytes to sites of inflammation $(1,2)$. In addition, they are recognized as molecules central for the normal development of lymphoid tissues, immune cell maturation/development, and immunological homeostasis (3).

Chemokines have a highly conserved, unique structure that has allowed a comprehensive in silico detection of characteristic patterns and a consistent classification in subfamilies (4). Four conserved signature cysteine residues linked by one to three disulfide bonds typically characterize the molecules. Depending on the position of two of the conserved cysteines near the $N$-terminus, they are categorized as CC (Cysteine-Cysteine; cysteines adjacent to each other) or CXC [cysteines separated by one non-conserved amino acid $(\mathrm{X})$ ] chemokines. These subfamilies are also known as $\beta$ - and $\alpha$-chemokines, respectively. Two further smaller classes of chemokines termed $\mathrm{C}(\gamma-)$ and $\mathrm{CX}_{3} \mathrm{C}(\delta-)$ chemokines exist with only two and one members, respectively (4).

Chemokines are usually secreted from the cell after their synthesis; but may become tethered to glycosaminoglycans (GAGs), a family of sulfated polysaccharides which can be located in the extracellular matrix or on the extracellular surface (5), or other sulfated sugars to form a stable local chemokine gradient and support the binding of a cognate chemokine receptor. This form of "haptotaxis," the movement along stable, immobilized gradients, has been described as the most likely physiological form (6) while gradients relying on soluble chemokines can only be envisaged as transient and short-lived in response to a local inflammatory stimulus.

The classical chemokine receptor has seven hydrophobic transmembrane domains arranged as $\alpha$-helices, an extracellular $N$ terminus and intracellular $C$-terminus (7). After binding to the cognate partner, signaling is transmitted by the G-proteins (8). Following ligand binding, the receptor is rapidly internalized, either via clathrin-mediated or caveolae-dependent endocytosis, in a process known as homologous desensitization, which protects the cell from over-stimulation (9). In addition, chemokine receptors are biochemically and functionally regulated by non-chemokine ligands interacting with their own cognate receptors (e.g., opioids/opioid receptors, vasoactive intestinal peptide, and its receptors); a process known as heterologous desensitization $(10,11)$. 
Chemokine genes tend to be genomically clustered, with human CXC chemokines located around chromosome 4q12-13 and CC chemokines around chromosome 17q11.2. Each main grouping tend to promiscuously share receptors of the same subtype (4).

\section{THE CCL20-CCR6 AXIS}

The cysteine-cysteine motif chemokine ligand 20 (CCL20) also known as liver- and activation-regulated chemokine (LARC), macrophage inflammatory protein-3 $\alpha$ (MIP-3 $\alpha$ ), and exodus-1 was discovered independently by three research groups using bioinformatics techniques (12-14). The chemokine CCL20 is encoded by the SCYA20 [small inducible cytokine family A (CysCys), member 20] gene (4). Unlike other CC chemokines, SCYA20 was localized to chromosome 2q33-q372 using a combination of PCR analysis of single chromosome DNA hybrids, yeast artificial chromosome clones, and radiation hybrid mapping $(4,14)$. The full length of human CCL20 cDNA contains 799 bp (4 exons and 3 introns), encoding an open reading frame of 95 or 96 AA (14-16). Since the putative cleavage site of this precursor protein is between Ala-26 and Ala-27, the mature form is a polypeptide with a length of $70 \mathrm{AA}$ (14). Interestingly, two variants of CCL20 cDNA were detected in which the shorter, truncated isoform had a deletion of three base pairs [one amino acid (Ala-27, GCA)] at the $N$-terminus (15). As a result, the two forms, which probably are the consequence of allelic polymorphism and use of different splicing sites, have been termed the Ala-27 and Ser-27 forms of CCL20. However, examination of the biological activity through chemotaxis assays of both revealed only a negligible difference in chemotactic profiles (15).

CCL20 is expressed in a variety of human tissues and by a range of immune cells. Based primarily on early expression assays utilizing Northern blots to detect CCL20 mRNA, constitutive expression was ascertained to be predominantly in human organassociated lymphoid tissue (lungs, lymph nodes, appendix, etc.), epithelial cells (including the intestines), and the liver; but surprisingly, virtually non-existent in spleen or bone marrow $(12,14,16$, 17). The presence of CCL20 in these tissues where active sites of inflammation and immune activation occur suggested that CCL20 was, to some extent, an inflammatory chemokine (12). Indeed, inflammation-related cells which have been shown to secrete or express CCL20 include endothelial cells $(18,19)$, neutrophils (20), natural killer (NK) cells (21), $\mathrm{T}_{\mathrm{H}} 17$ cells (22), B cells (23), and a variety of other immune cells [dendritic cells, DCs, Langerhan's cells (LCs), and macrophages] $(13,24)$.

\section{THE COGNATE RECEPTOR OF CCL20: CCR6}

As a unique feature among the CC chemokine family and consistent with its location on chromosome 2, CCL20 has a sole known receptor, CCR6 (25-27), and their interaction has been confirmed when CCL20 was able to induce calcium mobilization in K562 cells transfected with CCR6; but not with any other chemokine receptor CCR1-5 (27). In addition, 5 other CC chemokines tested (CCL2-5 and CCL17) failed to bind to CCR6 (27).

Upon binding of CCL20 to CCR6, the receptor is internalized, exhibiting decreased cell surface expression of CCR6 on splenocytes and especially on B cells (18). The receptor is found on a number of different immune cells, including CD34 ${ }^{+}$ hematopoietic precursor-derived DCs (28), memory T cells (29), and peripheral and memory B cells $(18,23,30)$. Early investigations into tissue expression were performed by Northern blot analysis, revealing significant presence in human liver, appendix, and lymph nodes, and minor presence in the thymus, testis, and small intestine (27). CCR6 mRNA is up-regulated in T cells by inflammatory stimuli (27). In B cells, it undergoes a series of up- and down-regulation during B cell development and activation $(23,31,32)$. This suggests that CCR6 is involved in both inflammatory and homeostatic roles in the immune system (33).

\section{CCL20 AND ITS RECEPTOR IN AN INFLAMMATORY ENVIRONIMENT}

The up-regulation of CCL20 in inflammation has been documented well in the literature. Under experimental conditions, various cytokines (IL- $1 \alpha$, IL- $\beta$, IL-17, IL-21, IFN- $\gamma$, TNF- $\alpha$ ) have been found to induce CCL20 expression at various micro-anatomical locations (34-36). In contrast, IL-4, IL-22, and IL-23 have been reported to have a negligible inductive effect on $\operatorname{CCL} 20(34,36)$ and application of the anti-inflammatory cytokine IL-10 downregulates CCL20 expression (12) as does the addition of IFN- $\gamma$ in synoviocytes (36). By utilizing CCL20 promoter region luciferasereporter constructs transfected into HEK293T, Caco-2, and G-361 cell lines, researchers identified a NF- $\kappa \mathrm{B}$ site upstream from the transcription start site that was, at least in part, responsible for the inflammatory responsiveness of CCL20 to TNF- $\alpha$ and IL- $\beta$ induction (37-39).

\section{ROLE OF CCL20-CCR6 AXIS IN DEVELOPMENT OF THE INTESTINAL IMMUNE SYSTEM}

Northern blot analysis of CCL20 expression shows high constitutive mRNA expression at mucosal sites such as the intestines, while CCR6 mRNA is only expressed at low to moderate levels (27). In a more detailed analysis of murine Peyer's patches (PP), CCL20 mRNA was found to be concentrated in the overlying follicle associated epithelium (FAE) whilst CCR6 mRNA could be detected in the sub-epithelial dome (SED) on $\mathrm{CD}_{11} \mathrm{~b}^{+} \mathrm{CD} 11 \mathrm{c}^{+} \mathrm{CD} 8 \mathrm{a}^{-}$ myeloid DCs (40). The latter expression was confirmed later on protein level in a study using an eGFP-CCR6 knock-in mouse strain (41). Furthermore, in the absence of CCR6, PP were smaller than their WT counterparts, yet were unchanged in absolute numbers and in proportions of lymphocytic subpopulations (42). Interestingly, intraepithelial lymphocytes were proportionally increased when compared to WT mice (42).

In a different study, a substantial expression of CCL20 was detected in isolated lymphoid follicles (ILF) and a number of developmental problems were noted in the intestinal lymphoid tissues of CCR6-deficient mice such as smaller PP displaying a reduced number of domes, and the absence of ILF (43). As a consequence of these immunological deficiencies, CCR6 ${ }^{-1-}$ mice show a diminished IgA response to rotavirus (33). Furthermore, it has been shown that the absence of CCR6 reduced intestinal M cell numbers $(44,45)$. Interestingly, because the bacteria Yersinia enterocolitica utilize $\mathrm{M}$ cells to cross the intestinal lumen, CCR6deficient mice have increased resistance to this microorganism compared to WT mice (46). Collectively, the above results point to a role of the CCL20-CCR6 axis in structural and functional aspects of the mucosal immune system of the intestines. 


\section{DEFENSINS}

A curious aspect of the CCL20-CCR6 axis in mucosal immunity is the relationship between CCL20 and $\beta$-defensins, small anti-microbial peptides found in epithelial tissue and at mucosal surfaces after inflammatory stimulus such as $\operatorname{TNF}(47,48)$. The human polypeptide $\beta$-defensin (type 1 and 2) is able to bind to CCR6 - potentially being capable of displacing CCL20 from its receptor - and hence act as a chemoattractant for CCR6-bearing immature DCs and various $\mathrm{T}$ cell subsets (49). This behavior can be explained by the structural similarities between defensins and CCL20. The two $\beta$-defensins each have a $\alpha$-helix and threestranded $\beta$-sheets at their $\mathrm{N}$-termini in an arrangement similar to human CCL20. In turn CCL20 is able to display direct antimicrobial activity in vitro (50). However, this aspect in CCL20CCR6 immunobiology has been challenged in recent years and inconsistencies in the literature exist. Whilst human $\beta$-defensins (hBDs) were chemotactic for macrophages, CCL20 failed to elicit such migration in vivo or in vitro (51). This suggests that another yet-to-be-identified receptor for $\beta$-defensins exists for chemoattraction. Indeed, a more recent study found that hBD-2 and -3 attracted human monocytes through interaction with CCR2 (52) and hence, this raises a possible alternative to the $\beta$-defensin-CCR6 relationship (53).

\section{BIOLOGY OF IBD AND MOUSE COLITIS MODELS}

Crohn's disease (CD) and ulcerative colitis (UC) are the two dominant subtypes of inflammatory bowel disease (IBD). Both are chronic inflammatory diseases of the intestinal tract; but while $\mathrm{CD}$ can involve any part of the intestinal system and presents with a transmural chronic inflammation spanning the entire intestinal wall, UC is limited to the colon, commencing distally, and the inflammation is confined to the mucosa and submucosa. The epidemiology of IBD shows a strong genetic predisposition for this chronic immune response, compounded by environmental factors such as microbiota and diet.

In humans, genome wide association studies (GWAS) have identified a plethora of genetic loci associated with IBD (54-57). These loci include genes that are associated with innate immune responses, such as NOD2, autophagy, such as ATG16L1 and with regulation of leukocyte migration such as the chemokine receptor CCR6 (55). This indicates that both regulatory and functional variations are associated with the generation of IBD. Furthermore, it has been demonstrated that CCL20 expression is up-regulated in human IBD biopsies predominately associated with FAE in a TNF-dependent manner, thus indicating a potential location for interaction between CCR6 ${ }^{+}$T cell subsets and DCs (58). Mouse models of acute colonic inflammation, however, are conflicting in their results. In the dextran sulfate sodium (DSS) model of colitis, CCR6 ${ }^{-1-}$ mice developed less severe colitis compared to WT mice (59), while in the 2,4,6-trinitrobenzene sulfonic acid (TNBS)-induced model, the clinical picture of colitis was stronger (60). In a third widely used classical model of colitis induced by $\mathrm{T}$ cell transfer, naïve $\mathrm{T}$ cells from $\mathrm{CCR} 6^{-1-}$ mice transferred into Rag $2^{-1-}$ mice caused a very severe colitis compared to CCR6 $6^{+/+}$ transferred $\mathrm{T}$ cells. In this model, $\mathrm{CCR}^{-1-} \mathrm{T}_{\text {reg }}$ cells displayed less suppressive capabilities and reduced migration to the site of inflammation compared to $\mathrm{WT}_{\mathrm{reg}}$ cells. This indicates that the protection from colitis is offered by a novel colon-homing, IL10-producing $\mathrm{CCR}^{+}{ }$regulatory $\mathrm{T}$ cell population (61). These results are in part explained by a recent report on the generation and education of a $T_{H} 17$ subset in the gut, which provided an interesting insight into the regulation of these inflammatory $\mathrm{T}$ cells $(62,63)$. Using a $\mathrm{T}$ cell-depletion model of colitis, it was demonstrated that $\mathrm{T}_{\mathrm{H}} 17$ cells accumulated in great numbers in the small intestine when a strong $\mathrm{T}$ cell receptor stimulus was present. More importantly, it was established that this $\mathrm{T}_{\mathrm{H}} 17 \mathrm{accu}-$ mulation was dependent on the CCL20-CCR6 axis and that these $\mathrm{T}_{\mathrm{H}} 17$ cells, interestingly, acquired an immunosuppressive phenotype in the gut, rather than the typical inflammatory phenotype associated with this cell subset (62). This was determined when the accumulated $\mathrm{T}_{\mathrm{H}} 17$ cells were able to suppress CFSE-labeled responder $\mathrm{T}$ cells $\left(\mathrm{CD} 4^{+} \mathrm{CD} 25^{-}\right)$in a suppression assay (in vitro) and prevent the establishment of EAE in experimental transfer models (in vivo). The likely mechanism of these cells is through the secretion of the immunosuppressive cytokine IL-10 (62).

\section{CCL20-CCR6 IN MUCOSAL TH17 AND Treg BIOLOGY}

The role that the CCL20-CCR6 axis has to play in steady-state dynamics is currently unclear; but the fact that opposing cell subtypes $\left(\mathrm{T}_{\mathrm{H}} 17\right.$ and $\mathrm{T}_{\text {reg }}$ cells) express and respond to CCL20 hints at a potential regulatory balance between immune activation and suppression, and implies an intriguing feedback loop (64). Already, CCL20 has been implicated in a network of effector and regulatory immune functions through the finding of CCR6 on the opposing $\mathrm{T}_{\mathrm{H}} 17$ and $\mathrm{T}_{\text {reg }}$ cells and CCL20 secretion from the former (22). Supporting the axis' functionality, experimental models of pathology have demonstrated the necessity for CCR6 in the recruitment of these cell types to the sites of inflammation following an up-regulation of CCL20 (65). In a Rag1 ${ }^{-/-}$severe combined immunodeficiency (SCID) model where CCR6 ${ }^{-1-}$ or WT $\mathrm{T}_{\mathrm{H}} 17$ cells were transferred in, a reduction in both $\mathrm{T}_{\mathrm{H}} 17$ and $\mathrm{T}_{\text {reg }}$ cells were seen in the recipient mice receiving the CCR6 ${ }^{-1-}$ cells. This, interestingly, resulted in more severe colitis in these animals (66). Paradoxically, mice deficient in CCR6 had an attenuated course of inflammation in an experimental autoimmune encephalomyelitis (EAE) model of disease (67). Collectively, these findings highlight the dynamic balance that exists between $\mathrm{T}_{\mathrm{H}} 17$ and $\mathrm{T}_{\text {reg }}$ cells and how the chemokine axis may be fundamental to ascertaining in which direction the balance is tipped. Some studies using $\mathrm{CCR6}^{-1-}$ mice seem to imply that CCR6 is functionally more important to $\mathrm{T}_{\text {reg }}$ cells than it is to $\mathrm{T}_{\mathrm{H}} 17$, resulting in more severe pathology in these knockout mice $(61,68)$.

Examination of organs of 5- to 7-week-old naive $\mathrm{BALB} / \mathrm{c}$ mice determined that most $\mathrm{T}_{\mathrm{H}} 17$ cells are found in small intestine, $\mathrm{PP}$, and colon at immunologic steady-state. In contrast, the $\mathrm{T}_{\text {reg }}$ cells are predominantly found in the bone marrow, colon, and peritoneal cavity (66). Interestingly, it appears that CCR6 is a dominant receptor for the migration of $\mathrm{T}_{\mathrm{H}} 17$ cells to $\mathrm{PP}$ (but not of $\mathrm{T}_{\text {regs }}$ ). This was supported through a later study that found the CCL20-CCR6 axis helps direct $\mathrm{T}_{\mathrm{H}} 17$ cells to the small intestine upon immune system induction. Furthermore, IL-17 secreted from $\mathrm{T}_{\mathrm{H}} 17$ cells up-regulates intestinal epithelial CCL20 which helps recruit these cells via the CCL20-CCR6 axis. Curiously, the CCR6-deficient mice had increased $\mathrm{T}_{\mathrm{H}} 17$ cells in the spleen 
and lymph nodes, suggesting that the effector cells are unable to migrate from the sites of induction. This resulted in less intestinal inflammation in these knockout mice as expected (62).

Quite a large number of effector $\mathrm{T}_{\mathrm{H}} 17$ cells can be found in the small intestine under steady-state conditions and during inflammation, compared to peripheral sites $(62,69)$. The precise roles that $\mathrm{T}_{\mathrm{H}} 17$ cells and their cytokines play in mucosal immunity have been the subject of a plethora of ongoing investigations. $\mathrm{T}_{\mathrm{H}} 17$ cells seem particularly important in mediating normal defense at mucosal sites, as demonstrated in $\mathrm{T}_{\mathrm{H}}$ 17- and IL-17-deficient mice that showed marked susceptibility to oral Candidiasis compared to WT counterparts (70). Additionally, in induced immunodeficiency mice models, the absence of $\mathrm{T}_{\mathrm{H}} 17$ cells allowed a greater dissemination of Salmonella typhimurium, from the gut to other parts of the body (71). Indeed, the means of protection under steady-state conditions appear to be through the cells' ability to organize the immunological and microbiological barriers against potentially harmful pathogens (72). Therefore, the CCL20-CCR6 axis, which appears to be integral to $\mathrm{T}_{\mathrm{H}} 17$ homing and function, is important for steady-state mucosal immunity in the gut.

The microbiological environment of the small intestines has been shown to have a dominant reciprocal effect on $\mathrm{T}_{\mathrm{H}} 17$ cell quantity with studies showing that intestinal microbiota are necessary for steady-state colonization and maintenance of the cells (73, 74). In support of this observation, mice treated with antibiotics had their intestinal $\mathrm{T}_{\mathrm{H}} 17$ cell population essentially ablated (73). In addition, mice that were housed in a germ-free environment therefore lacking intestinal microbiota - not only had reduced $\mathrm{T}_{\mathrm{H}} 17$ colonization but had a reciprocal increase in the FoxP3 ${ }^{+}$ regulatory $\mathrm{T}$ cells suggesting that the microbiota influences the $\mathrm{T}_{\mathrm{H}} 17-\mathrm{T}_{\text {reg }}$ balance in the gut (74). Finally, the colonization of the intestines by the $\mathrm{T}_{\mathrm{H}} 17$ subset is also functionally necessary as it is associated with protection against intestinal pathogens such as Citrobacter rodentium (73). Mice deficient for the $\mathrm{T}_{\mathrm{H}} 17$ subsetassociated pro-inflammatory cytokine IL-21 were consequently protected against the development of DSS colitis and failed to up-regulate other critical $\mathrm{T}_{\mathrm{H}} 17$-associated molecules such as IL17 and ROR- $\gamma \mathrm{t}$, which could be confirmed in the TNBS-induced colitis model (75).

These findings imply that the CCL20-CCR6 axis, in conjunction with the microbiota, have dominant effects on regulating the $\mathrm{T}_{\mathrm{H}} 17-\mathrm{T}_{\text {reg }}$ balance and are therefore influencing the pathogenesis of colitis. Future studies to explore this aspect can employ the use of other mouse models to further clarify the relationship between CCR6, $\mathrm{T}_{\mathrm{H}} 17$ cells, and colitis. One such model is the so-called

\section{REFERENCES}

1. Sallusto F, Baggiolini M. Chemokines and leukocyte traffic. Nat Immunol (2008) 9(9):949-52. doi:10.1038/ ni.f. 214

2. Baggiolini $\mathrm{M}$, Loetscher $\mathrm{P}$. Chemokines in inflammation and immunity. Immunol Today (2000) 21(9):418-20. doi:10.1016/S01675699(00)01672-8
3. Ansel KM, Cyster JG. Chemokines in lymphopoiesis and lymphoid organ development. Curr Opin Immunol (2001) 13(2):172-9.

4. Zlotnik A, Yoshie O. Chemokines: a new classification system and their role in immunity. Immunity (2000) 12(2):121-7. doi:10.1016/S10747613(00)80165-X
Winnie mouse strain $(76,77)$, which is a model of IBD, based on a single point mutation of the Muc2 mucin gene generated by ENU mutagenesis. This mutation results in a proportion of the MUC2 protein misfolding and accumulating in the endoplasmic reticulum (ER) resulting in ER stress in intestinal goblet cells, a depleted intestinal mucus barrier and spontaneous colonic inflammation (78). The distal colon segment showed significant increase in the expression of $\mathrm{T}_{\mathrm{H}} 17$ signature genes; Il17a, Ill7f, Tgfß , and Ccr6 were detectable suggesting a $\mathrm{T}_{\mathrm{H}} 17$ polarization. Hence, this novel model is ideally suited to study the role of CCR6 and $\mathrm{T}_{\mathrm{H}} 17$ cells in intestinal immune responses.

\section{CONCLUSION}

The unique CCL20-CCR6 axis poses as a dilemma for researchers into IBD and other diseases. There is little doubt that the pair is involved in mucosal immunity and IBD; but because of its participation in the opposing $\mathrm{T}_{\mathrm{H}} 17$ and $\mathrm{T}_{\text {reg }}$ cell activities as well as $\mathrm{B}$ cell activation and antigen presentation, ascertaining its overall involvement in pro- or anti-inflammatory activities poses some difficulties. The differing approaches and experimental techniques may account for some of the contradictions in the above results of the precise contributions of the CCL20-CCR6 pair to IBD. A fundamental problem is that many studies rely on well established but not tissue-specific Ccr6 gene knockout mice while CCL20 ${ }^{-1-}$ mice do not yet exist. Therefore, unanswered questions remain: is the CCL20-CCR6 axis centrally involved in the development of inflammatory diseases of the bowel (axis of evil) or is it just a pair of cellular navigational tools that seemingly interfere with disease pathogenesis as an epiphenomenal artifact of a general knockout mouse (odd couple)? This question can be answered when better tools such as tissue-specific knockouts are available. Furthermore, we have to wonder how the axis can contribute to inflammatory cell recruitment yet confer suppression at the same time through the opposing $\mathrm{T}_{\mathrm{H}} 17$ and $\mathrm{T}_{\text {reg }}$ cells. Adding to the confusion, what role, if any, does the axis play in regulating the inflammatory versus regulatory $\mathrm{T}_{\mathrm{H}} 17$ cells? The answer to this question and others may lie in the combination of other regulatory factors, such as other chemokines, which recruit and "switch on" pro- or antiinflammatory cells during IBD and will have to be addressed and dissected in more detail in further studies.

\section{ACKNOWLEDGMENTS}

This work was supported by the National Health and Medical Research Council of Australia. Adrian Y. S. Lee was supported by a scholarship from the School of Medicine, University of Tasmania.
5. Proudfoot AE, Handel TM, Johnson Z, Lau EK, LiWang P, ClarkLewis I, et al. Glycosaminoglycan binding and oligomerization are essential for the in vivo activity of certain chemokines. Proc Natl Acad Sci U S A (2003) 100(4): 1885-90. doi:10.1073/pnas.0334 864100

6. Weber M, Hauschild R, Schwarz J, Moussion C, de Vries I, Legler
DF, et al. Interstitial dendritic cell guidance by haptotactic chemokine gradients. Science (2013) 339(6117):328-32. doi:10.1126/science.1228456

7. Allen SJ, Crown SE, Handel TM. Chemokine: receptor structure, interactions, and antagonism. Annu Rev Immunol (2007) 25:787-820. doi:10.1146/ann urev.immunol.24.021605.090529 
8. Neptune ER, Iiri T, Bourne HR. Galphai is not required for chemotaxis mediated by Gi-coupled receptors. J Biol Chem (1999) 274(5):2824-8. doi:10.1074/jbc.274.5.2824

9. Mueller A, Kelly E, Strange PG. Pathways for internalization and recycling of the chemokine receptor CCR5. Blood (2002) 99(3):785-91. doi:10.1182/blood.V99.3.785

10. Grimm MC, Ben-Baruch A, Taub DD, Howard OM, Resau JH, Wang JM, et al. Opiates transdeactivate chemokine receptors: delta and mu opiate receptor-mediated heterologous desensitization. J Exp Med (1998) 188(2):317-25. doi:10.1084/jem.188.2.317

11. Grimm MC, Newman R, Hassim Z, Cuan N, Connor SJ, Le Y, et al. Cutting edge: vasoactive intestinal peptide acts as a potent suppressor of inflammation in vivo by transdeactivating chemokine receptors. J Immunol (2003) 171(10): 4990-4.

12. Rossi DL, Vicari AP, Franz-Bacon K, McClanahan T, Zlotnik A. Identification through bioinformatics of two new macrophage proinflammatory human chemokines: MIP- $3 \alpha$ and MIP-3 $\beta$. J Immunol (1997) 158:1033-6.

13. Hromas R, Gray PW, Chantry D, Godiska R, Krathwohl M, Fife $\mathrm{K}$, et al. Cloning and characterization of exodus, a novel beta-chemokine. Blood (1997) 89(9):3315-22.

14. Hieshima K, Imai T, Opdenakker G, Van Damme J, Kusuda J, Tei $\mathrm{H}$, et al. Molecular cloning of a novel human CC chemokine liver and activation-regulated chemokine (LARC) expressed in liver. Chemotactic activity for lymphocytes and gene localization on chromosome 2. J Biol Chem (1997) 272(9):5846-53. doi:10.1074/jbc.272.9.5846

15. Nelson RT, Boyd J, Gladue RP, Paradis T, Thomas R, Cunningham $\mathrm{AC}$, et al. Genomic organization of the CC chemokine mip-3alpha/CCL20/larc/exodus/ SCYA20, showing gene structure, splice variants, and chromosome localization. Genomics (2001) 73(1):28-37. doi:10.1006/geno.2001.6482

16. Yoshie O, Imai $\mathrm{T}$, Nomiyama H. Novel lymphocyte-specific CC chemokines and their receptors. $J$ Leukoc Biol (1997) 62:634-44.

17. Hromas R, Kim CH, Klemsz M, Krathwohl M, Fife K, Cooper
$\mathrm{S}$, et al. Isolation and characterization of Exodus-2, a novel $\mathrm{C}-\mathrm{C}$ chemokine with a unique 37-amino acid carboxyl-terminal extension. J Immunol (1997) 159(6):2554-8.

18. Meissner A, Zilles O, Varona R, Jozefowski K, Ritter U, Marquez $\mathrm{G}$, et al. CC chemokine ligand 20 partially controls adhesion of naive $B$ cells to activated endothelial cells under shear stress. Blood (2003) 102(8):2724-7. doi:10.1182/blood-2003-01-0007

19. Kriehuber E, Breiteneder-Geleff S, Groeger M, Soleiman A, Schoppmann SF, Stingl G, et al. Isolation and characterization of dermal lymphatic and blood endothelial cells reveal stable and functionally specialized cell lineages. $J$ Exp Med (2001) 194(6):797-808. doi:10.1084/jem.194.6.797

20. Scapini P, Laudanna C, Pinardi C, Allavena P, Mantovani A, Sozzani $\mathrm{S}$, et al. Neutrophils produce biologically active macrophage inflammatory protein3alpha (MIP-3alpha)/CCL20 and MIP-3beta/CCL19. Eur J Immunol (2001) 31(7):1981-8. doi:10.1002/15214141(200107)31:7<1981::AIDIMMU1981>;3.0.CO;2-X

21. Cella M, Fuchs A, Vermi W, Facchetti F, Otero K, Lennerz JK, et al. A human natural killer cell subset provides an innate source of IL-22 for mucosal immunity. Nature (2009) 457(7230):722-5. doi:10.1038/nature07537

22. Yamazaki T, Yang XO, Chung Y, Fukunaga A, Nurieva R, Pappu B, et al. CCR6 regulates the migration of inflammatory and regulatory T cells. J Immunol (2008) 181(12):8391-401.

23. Bowman EP, Campbell JJ, Soler D, Dong Z, Manlongat $\mathrm{N}$, Picarella D, et al. Developmental switches in chemokine response profiles during $B$ cell differentiation and maturation. J Exp Med (2000) 191:1303-18. doi:10.1084/jem.191.8.1303

24. Shimizu Y, Murata H, Kashii Y, Hirano K, Kunitani H, Higuchi K, et al. CC-chemokine receptor 6 and its ligand macrophage inflammatory protein 3alpha might be involved in the amplification of local necroinflammatory response in the liver. Нераtology (2001) 34(2):311-9. doi:10.1053/jhep.2001.26631

25. Varona R, Zaballos A, Gutierrez J, Martin P, Roncal F, Albar JP, et al. Molecular cloning, functional characterization and mRNA expression analysis of the murine chemokine receptor CCR6 and its specific ligand MIP-3alpha. FEBS Lett (1998) 440(12):188-94. doi:10.1016/S00145793(98)01450-1

26. Liao F, Alderson R, Su J, Ullrich SJ, Kreider BL, Farber JM. STRL22 is a receptor for the CC chemokine MIP-3alpha. Biochem Biophys Res Commun (1997) 236(1):212-7. doi:10.1006/bbrc.1997.6936

27. Baba $M$, Imai $T$, Nishimura M, Kakizaki M, Takagi S Hieshima K, et al. Identification of CCR6, the specific receptor for a novel lymphocyte-directed CC chemokine LARC. J Biol Chem (1997) 272(23):14893-8. doi:10.1074/jbc.272.23.14893

28. Greaves DR, Wang W, Dairaghi DJ, Dieu MC, de Saint-Vis B, Franz-Bacon K, et al. CCR6, a $\mathrm{CC}$ chemokine receptor that interacts with macrophage inflammatory protein $3 \alpha$ and is highly expressed in human dendritic cells. J Exp Med (1997) 186:83744. doi:10.1084/jem.186.6.837

29. Liao F, Rabin RL, Smith CS Sharma G, Nutman TB, Farber JM. CC-chemokine receptor 6 is expressed on diverse memory subsets of $\mathrm{T}$ cells and determines responsiveness to macrophage inflammatory protein 3 alpha. Immunol (1999) 162(1):186-94.

30. Schwickert TA, Victora GD, Fooksman DR, Kamphorst AO, Mugnier MR, Gitlin AD, et al. A dynamic T cell-limited checkpoint regulates affinity-dependent $\mathrm{B}$ cell entry into the germinal center. Exp Med (2011) 208(6):1243-52. doi:10.1084/jem.20102477

31. Krzysiek R, Lefevre EA, Bernard J, Foussat A, Galanaud P, Louache $F$, et al. Regulation of CCR6 chemokine receptor expression and responsiveness to macrophage inflammatory protein-3alpha/CCL20

human B cells. Blood (2000) 96(7):2338-45.

32. Wiede F, Vana K, Sedger LM, Lechner A, Körner H. TNF-dependent overexpression of CCL21 is an underlying cause of progressive lymphoaccumulation in generalized lymphoproliferative disorder. Eur J Immunol (2007) 37(2):3517. doi:10.1002/eji.200636218

33. Cook DN, Prosser DM, Forster R, Zhang J, Kuklin NA, Abbondanzo SJ, et al. CCR6 mediates dendritic cell localization, lymphocyte homeostasis, and immune responses in mucosal tissue. Immunity (2000) 12(5):495503. 7613(00)80201-0

34. Nakayama T, Fujisawa R, Yamada $\mathrm{H}$, Horikawa T, Kawasaki $\mathrm{H}$ Hieshima $\mathrm{K}$, et al. Inducible expression of a CC chemokine liver- and activation-regulated chemokine (LARC)/macrophage inflammatory protein (MIP)3 alpha/CCL20 by epidermal keratinocytes and its role in atopic dermatitis. Int Immunol (2001) 13(1):95-103. doi:10.1093/intimm/13.1.95

35. Starner TD, Barker CK, Jia HP, Kang Y, McCray PB Jr. CCL20 is an inducible product of human airway epithelia with innate immune properties. Am J Respir Cell Mol Biol (2003) 29(5):627-33. doi:10.1165/rcmb.2002-0272OC

36. Hirota $\mathrm{K}$, Yoshitomi $\mathrm{H}$ Hashimoto M, Maeda S, Teradaira S, Sugimoto N, et al. Preferential recruitment of CCR6-expressing Th17 cells to inflamed joints via CCL20 in rheumatoid arthritis and its animal model. $J$ Exp Med (2007) 204(12):2803-12. doi:10.1084/jem.20071397

37. Fujiie $\mathrm{S}$, Hieshima $\mathrm{K}$, Izawa D, Nakayama T, Fujisawa R, Ohyanagi $\mathrm{H}$, et al. Proinflammatory cytokines induce liver and activation-regulated chemokine/macrophage inflammatory protein-3alpha/CCL20 in mucosal epithelial cells through NF-kappaB [correction of NK-kappaB]. Int Immunol (2001) 13(10):1255-63. doi:10.1093/intimm/13.10.1255

38. Harant H, Eldershaw SA, Lindley IJ. Human macrophage inflammatory protein3alpha/CCL20/LARC/Exodus/ SCYA20 is transcriptionally upregulated by tumor necrosis factor-alpha via a non-standard NF-kappaB site. FEBS Lett (2001) 509(3):43945 5793(01)03138-6

39. Sugita S, Kohno T, Yamamoto $\mathrm{K}$, Imaizumi $\mathrm{Y}$, Nakajima $\mathrm{H}$, Ishimaru $\mathrm{T}$, et al. Induction of macrophage-inflammatory protein-3alpha gene expression by TNF-dependent NF-kappaB activation. J Immunol (2002) 168(11):5621-8.

40. Iwasaki A, Kelsall BL. Localization of distinct Peyer's patch dendritic cell subsets and their recruitment by chemokines macrophage inflammatory 
protein (MIP)-3alpha, MIP3beta, and secondary lymphoid organ chemokine. $J$ Exp Med (2000) 191(8):1381-94. doi:10.1084/jem.191.8.1381

41. Kucharzik T, Hudson JT III, Waikel RL, Martin WD, Williams IR. CCR6 expression distinguishes mouse myeloid and lymphoid dendritic cell subsets: demonstration using a CCR6 EGFP knock-in mouse. Eur J Immunol (2002) 32(1):104-12. doi:10.1002/15214141(200201)32:1<104::AIDIMMU104 >33.0.CO;2-C

42. Varona R, Villares R, Carramolino L, Goya I, Zaballos A, Gutierrez J, et al. CCR6-deficient mice have impaired leukocyte homeostasis and altered contact hypersensitivity and delayedtype hypersensitivity responses. J Clin Invest (2001) 107(6):37-45. doi:10.1172/JCI11297

43. McDonald KG, McDonough JS, Wang C, Kucharzik T, Williams IR, Newberry RD. CC chemokine receptor 6 expression by $B$ lymphocytes is essential for the development of isolated lymphoid follicles. Am J Pathol (2007) 170(4):1229-40. doi:10.2353/ajpath.2007.060817

44. Ebisawa M, Hase K, Takahashi D, Kitamura H, Knoop KA, Williams IR, et al. CCR6hiCD11c(int) $B$ cells promote M-cell differentiation in Peyer's patch. Int Immunol (2011) 23(4):261-9. doi:10.1093/intimm/dxq478

45. Lugering A, Floer M, Westphal S, Maaser C, Spahn TW, Schmidt $\mathrm{MA}$, et al. Absence of CCR6 inhibits $\mathrm{CD} 4+$ regulatory T-cell development and M-cell formation inside Peyer's patches. Am J Pathol (2005) 166(6):1647$54 . \quad$ doi:10.1016/S00029440(10)62475-3

46. Westphal $S$, Lugering $A$, von Wedel J, von Eiff C, Maaser C, Spahn T, et al. Resistance of chemokine receptor 6-deficient mice to Yersinia enterocolitica infection: evidence of defective M-cell formation in vivo. Am J Pathol (2008) 172(3):671-80. doi:10.2353/ajpath.2008.070393

47. Diamond G, Russell JP, Bevins CL. Inducible expression of an antibiotic peptide gene in lipopolysaccharidechallenged tracheal epithelial cells. Proc Natl Acad Sci U S A (1996) 93(10):5156-60. doi:10.1073/pnas.93.10.5156

48. Russell JP, Diamond G, Tarver AP, Scanlin TF, Bevins CL.
Coordinate induction of two antibiotic genes in tracheal epithelial cells exposed to the inflammatory mediators lipopolysaccharide and tumor necrosis factor alpha. Infect Immun (1996) 64(5): 1565-8.

49. Yang D, Chertov O, Bykovskaia SN, Chen Q, Buffo MJ, Shogan $\mathrm{J}$, et al. Beta-defensins: linking innate and adaptive immunity through dendritic and $\mathrm{T}$ cell CCR6. Science (1999) 286(5439): 525-8. doi:10.1126/science.286.54 39.525

50. Hoover DM, Boulegue C, Yang D, Oppenheim JJ, Tucker K, Lu $\mathrm{W}$, et al. The structure of human macrophage inflammatory protein-3alpha/CCL20. Linking antimicrobial and $\mathrm{CC}$ chemokine receptor-6-binding activities with human beta-defensins. $J$ Biol Chem (2002) 277(40):37647-54. doi:10.1074/jbc.M203907200

51. Soruri A, Grigat J, Forssmann U, Riggert J, Zwirner J. Beta-defensins chemoattract macrophages and mast cells but not lymphocytes and dendritic cells: CCR6 is not involved. Eur J Immunol (2007) 37(9):2474-86. doi:10.1002/eji.200737292

52. Rohrl J, Yang D, Oppenheim JJ, Hehlgans T. Human beta-defensin 2 and 3 and their mouse orthologs induce chemotaxis through interaction with CCR2. J Immunol (2010) 184(12):6688-94. doi:10.4049/jimmunol.0903984

53. Rohrl J, Yang D, Oppenheim JJ, Hehlgans T. Specific binding and chemotactic activity of $\mathrm{mBD} 4$ and its functional orthologue hBD2 to CCR6-expressing cells. $\mathrm{J}$ Biol Chem (2010) 285(10):7028-34. doi:10.1074/jbc.M109.091090

54. Anderson CA, Boucher G, Lees CW, Franke A, D'Amato M, Taylor KD, et al. Meta-analysis identifies 29 additional ulcerative colitis risk loci, increasing the number of confirmed associations to 47 . Nat Genet (2011) 43(3):246-52. doi:10.1038/ng0911-919b

55. Barrett JC, Hansoul S, Nicolae DL, Cho JH, Duerr RH, Rioux JD, et al. Genome-wide association defines more than 30 distinct susceptibility loci for Crohn's disease. Nat Genet (2008) 40(8):955-62. doi:10.1038/ng. 175

56. Franke A, McGovern DP, Barrett JC, Wang K, Radford-Smith GL, Ahmad T, et al. Genomewide meta-analysis increases to 71 the number of confirmed Crohn's disease susceptibility loci.
Nat Genet (2010) 42(12):1118-25. doi:10.1038/ng.717

57. Imielinski $\mathrm{M}$, Baldassano $\mathrm{RN}$, Griffiths A, Russell RK, Annese $\mathrm{V}$, Dubinsky $\mathrm{M}$, et al. Common variants at five new loci associated with early-onset inflammatory bowel disease. Nat Genet (2009) 41(12):1335-40. doi:10.1038/ng.489

58. Kaser A, Ludwiczek O, Holzmann S, Moschen AR, Weiss G, Enrich $B$, et al. Increased expression of CCL20 in human inflammatory bowel disease. $J$ Clin Immunol (2004) 24(1):74-85. doi:10.1023/B:JOCI.0000018066. $46279.6 \mathrm{~b}$

59. Varona R, Cadenas V, Flores J, Martinez AC, Marquez G. CCR6 has a non-redundant role in the development of inflammatory bowel disease. Eur Immunol (2003) 33(10):2937-46. doi:10.1002/eji.200324347

60. Katchar K, Kelly CP, Keates S, O'Brien MJ, Keates AC. MIP3alpha neutralizing monoclonal antibody protects against TNBSinduced colonic injury and inflammation in mice. Am J Physiol Gastrointest Liver Physiol (2007) 292(5):G1263-71.

61. Kitamura K, Farber JM, Kelsall BL. CCR6 marks regulatory $\mathrm{T}$ cells as a colon-tropic, IL-10producing phenotype. J Immuno (2010) 185(6):3295-304 doi:10.4049/jimmunol.1001156

62. Esplugues E, Huber S, Gagliani $\mathrm{N}$, Hauser AE, Town $\mathrm{T}$, Wan YY, et al. Control of TH17 cells occurs in the small intestine. Nature (2011) 475(7357):514-8. doi:10.1038/nature10228

63. Voo KS, Wang YH, Santori FR, Boggiano C, Wang YH, Arima $\mathrm{K}$, et al. Identification of IL17-producing FOXP3+ regulatory T cells in humans. Proc Nat Acad Sci U S A (2009) 106(12): 4793-8. doi:10.1073/pnas.09004 08106

64. Comerford I, Bunting M, Fenix K, Haylock-Jacobs S, Litchfield W, Harata-Lee Y, et al. An immune paradox: how can the same chemokine axis regulate both immune tolerance and activation? CCR6/CCL20: a chemokine axis balancing immunological tolerance and inflammation in autoimmune disease. Bioessays (2010) 32(12):1067-76. doi:10.1002/bies.201000063

65. Turner JE, Paust HJ, Steinmetz OM, Peters A, Riedel JH, Erhardt A, et al. CCR6 recruits regulatory $\mathrm{T}$ cells and Th17 cells to the kidney in glomerulonephritis. J Am Soc Nephrol (2010) 21(6):974-85. doi:10.1681/ASN . 2009070741

66. Wang C, Kang SG, Lee J, Sun $\mathrm{Z}$, Kim $\mathrm{CH}$. The roles of CCR6 in migration of Th17 cells and regulation of effector T-cell balance in the gut. Mucosal Immunol (2009) 2(2):173-83. doi:10.1038/mi.2008.84

67. Liston A, Kohler RE, Townley S, Haylock-Jacobs S, Comerford $\mathrm{I}$, Caon AC, et al. Inhibition of CCR6 function reduces the severity of experimental autoimmune encephalomyelitis via effects on the priming phase of the immune response. $J$ Immunol (2009) 182(5):3121-30. doi:10.4049/jimmunol.0713169

68. Barth T, Schmidt D, Botteron C, Nguyen TT, Ritter U, Mannel DN, et al. An early reduction in Treg cells correlates with enhanced local inflammation in cutaneous leishmaniasis in CCR6-deficient mice. PLoS ONE (2012) 7(9):e44499. doi:10. 1371/journal.pone.0044499

69. Ivanov II, McKenzie BS, Zhou L, Tadokoro CE, Lepelley A, Lafaille JJ, et al. The orphan nuclear receptor RORgammat directs the differentiation program of proinflammatory $\mathrm{IL}-17+\mathrm{T}$ helper cells. Cell (2006) 126(6):1121-33. doi:10.1016/j.cell.2006.07.035

70. Conti HR, Shen F, Nayyar N, Stocum E, Sun JN, Lindemann MJ, et al. Th17 cells and IL-17 receptor signaling are essential for mucosal host defense against oral Candidiasis. J Exp Med (2009) 206(2):299_ 311. doi:10.1084/jem.20081463

71. Raffatellu M, Santos RL, Verhoeven DE, George MD, Wilson RP, Winter SE, et al. Simian immunodeficiency virus-induced mucosal interleukin-17 deficiency promotes Salmonella dissemination from the gut. Nat Med (2008) 14(4):421-8. doi:10.1038/ $\mathrm{nm} 1743$

72. Blaschitz C, Raffatellu M. Th17 cytokines and the gut mucosal barrier. $J$ Clin Immunol (2010) 30(2): 196-203. doi:10.1007/s10875010-9368-7

73. Ivanov II, Atarashi K, Manel N, Brodie EL, Shima T, Karaoz U, et al. Induction of intestinal Th17 cells by segmented filamentous bacteria. Cell (2009) 139(3): 485-98. doi:10.1016/j.cell.2009. 09.033 
74. Ivanov II, Frutos Rde L, Manel N, Yoshinaga K, Rifkin DB, Sartor $\mathrm{RB}$, et al. Specific microbiota direct the differentiation of IL17-producing $\mathrm{T}$-helper cells in the mucosa of the small intestine. Cell Host Microbe (2008) 4(4): 337-49. doi:10.1016/j.chom.2008. 09.009

75. Fina D, Sarra M, Fantini MC, Rizzo A, Caruso R, Caprioli F, et al. Regulation of gut inflammation and th17 cell response by interleukin-21. Gastroenterology (2008) 134(4):1038-48. doi:10.1053/j.gastro.2008.01.041

76. Eri R, McGuckin MA, Wadley R. $\mathrm{T}$ cell transfer model of colitis: a great tool to assess the contribution of $\mathrm{T}$ cells in chronic intestinal inflammation. Methods Mol Biol (2012) 844:261-75. doi:10.1007/978-1-61779-5275_19

77. Eri RD, Adams RJ, Tran TV, Tong H, Das I, Roche DK, et al. An intestinal epithelial defect conferring ER stress results in inflammation involving both innate and adaptive immunity. Mucosal Immunol (2010) 4(3):354-64. doi:10.1038/mi.2010.74

78. Heazlewood CK, Cook MC, Eri R, Price GR, Tauro SB, Taupin D, et al. Aberrant mucin assembly in mice causes endoplasmic reticulum stress and spontaneous inflammation resembling ulcerative colitis. PLoS Med (2008) 5(3):e54. doi:10. 1371/journal.pmed.0050054

Conflict of Interest Statement: The authors declare that the research was conducted in the absence of any commercial or financial relationships that could be construed as a potential conflict of interest.

Received: 28 April 2013; accepted: 02 July 2013; published online: 15 July 2013.

Citation: Lee AYS, Eri R, Lyons $A B$,

Grimm MC and Korner H (2013)
CC chemokine ligand 20 and its cognate receptor CCR6 in mucosal $T$ cell immunology and inflammatory bowel disease: odd couple or axis of evil? Front. Immunol. 4:194. doi: 10.3389/fimmu.2013.00194

This article was submitted to Frontiers in Mucosal Immunity, a specialty of Frontiers in Immunology.

Copyright (ㅇ 2013 Lee, Eri, Lyons, Grimm and Korner. This is an open-access article distributed under the terms of the Creative Commons Attribution License, which permits use, distribution and reproduction in other forums, provided the original authors and source are credited and subject to any copyright notices concerning any third-party graphics etc. 